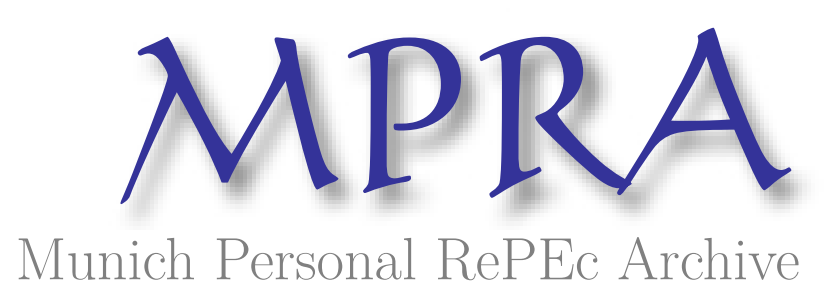

\title{
Exchange Rate Pass-through in ASEAN Countries: An Application of the SVAR Model
}

Vo, Duc

Ho Chi Minh City Open University, Vietnam

30 May 2018

Online at https://mpra.ub.uni-muenchen.de/103283/

MPRA Paper No. 103283, posted 20 Oct 2020 08:02 UTC 


\title{
Exchange Rate Pass-Through in ASEAN Countries:
}

\author{
An Application of the SVAR model ${ }^{1}$
}

Vo The Anh, Le Thai Thuong Quan,

Nguyen Van Phuc, Ho Minh Chi, Vo Hong Duc ${ }^{2}$

Business and Economics Research Group

Ho Chi Minh City Open University Vietnam

This work was supported by the Ho Chi Minh City Open University Vietnam [E2017.6.15.1 Decision 901/QĐĐHM dated 15/06/2017].

$2 \quad$ Corresponding author can be contacted at duc.vhong@ou.edu.vn 


\title{
Exchange Rate Pass-Through in ASEAN Countries:
}

\section{An Application of the SVAR model}

\begin{abstract}
Central banks in emerging countries generally question the effect of exchange rate passthrough into price levels in the national economy in order to implement monetary policy effectively. This paper is conducted in response to these macroeconomic concerns. Five founding members of the Association of Southeast Asian Nations (ASEAN), for which all the required data are available, are included in our sample with up-to-date time-series data until 2016. We use a structural vector autoregressive model in this study. Several interesting findings emerged from our study. First, we find incomplete exchange rate pass-through to domestic prices, and the producer price index is found to be affected more than the consumer price index. Second, the exchange rate shocks are found to have an immediate effect within one quarter on producer prices in all the countries. Third, variance in domestic prices is found to be caused mainly by shocks from oil prices, output gaps, and exchange rates, with some differences in the extent of effects across countries. Fourth, in these five countries, interest rates appear to play a minor role in explaining the inflation rate. We recommend that policy makers pursuing price stability in the economy focus on exchange rates and interest rate policy with great caution.

Key words: ASEAN, exchange rate pass-through, inflation, structural VAR

JEL Classification: $\quad$ E31, F52, F31
\end{abstract}




\section{Introduction}

In research on international finance, the exchange rate pass-through (ERPT) has attracted a great deal of interest among academics, practitioners, and policy makers for several decades. This passthrough refers to the degree to which exchange rate variations pass through to price-level changes. A wide range of price levels have been studied, from disaggregated import prices (Saha and Zhang 2016) and aggregated import prices (Alvarez, Jaramillo, and Selaive 2012; Camba and Goldberg 2005; Kiliç 2015) to consumer prices (Jiang and Kim 2013) and even either producer prices (Prasertnukul, Kim, and Kakinaka 2010) and export prices (Choudhri and Hakura 2014; Saha and Zhang 2016; Toh and Ho 2001; Zhang and Li 2017).

The ERPT is of great importance to policy makers for determining proper monetary policy, especially in the Southeast Asia, where regional economic integration, such as the formation of the Association of Southeast Asian Nations (ASEAN), has been considered a strong and sustainable force for economic growth and development in the future. On the one hand, a high degree of ERPT could transmit shocks from foreign to domestic prices (inflation), which provides robust grounds for adopting a specific exchange rate regime in a country (Ghosh 2013). On the other hand, when the ERPT is low, a country can have more flexibility in the pursuit of independent monetary policy in which inflation targeting can be conducted easily (Choudhri and Hakura 2006). In addition, low ERPT is associated with a smaller external response. For example, depreciation in a domestic currency does not help improve a trade deficit or increase exports when the economy is collapsing (Ito and Sato 2008).

This research reexamines the degree of ERPT into producer prices and consumer prices in five founding ASEAN member countries: Indonesia, Malaysia, Philippines, Singapore, and Thailand. This paper makes the following contributions. First, although many studies focus on the 
ERPT in ASEAN, most of them employ a single equation technique or consider the pass-through before the global financial crisis in 2008, as indicated in Appendix 1. However, our work is based on up-to-date data and a method that is more appropriate for depicting ERPT in ASEAN. A structural vector autoregressive (SVAR) model, impulse-response functions (IRFs), and variance decomposition are all combined to investigate the degree to which ERPT shifts from producer prices to consumer prices, leading to inflation in the economy. Second, we offer a complete understanding of the complex relationship among exchange rates, inflation, and changes in producer prices. This helps countries to design an appropriate strategy for not only exchange rates but other macroeconomic interventions. Third, our contribution to the literature on ERPT comes from focusing on small, open economies, which allows comparison with previous studies on the region as well as those on developed countries.

The paper is structured as follows. Following the Introduction, Section 2 gives a brief literature review regarding theory and empirical evidence. A research analytical framework is in Section 3. Data and our empirical findings are presented in Section 4, followed by concluding remarks in Section 5.

\section{Literature Review}

The theory of exchange rate pass-through has developed from a debate over the failure of the law of one price and purchasing power parity to the foundation of industrial organization models and pricing to market (Cortinhas 2009). More recently, debates have emerged over the appropriate monetary policy and the optimal choice of exchange rate regime, which stem from substantial empirical evidence on the limited pass-through of nominal exchange rate movements. Various empirical papers have acknowledged that the ERPT makes a significant contribution to price 
levels, but they vary in terms of the data studied, the econometric techniques used, and the countries analyzed.

Existing empirical studies on the ERPT have mainly employed two econometrics methods. The first method utilizes a single equation with time-series data or panel data (Baharumshah, Soon, and Wohar 2017; Barhoumi 2006; Campa and Goldberg 2005; Kiliç 2015; Prasertnukul et al. 2010). For example, using panel data on 23 member countries in the Organization for Economic Cooperation and Development (OECD), Campa and Golberg (2005) find partial ERPT to import prices in the short run, especially in manufacturing. Barhoumi (2006) tests a hypothesis on homogeneity among pass-through rates across developing countries, using non-stationary panel techniques and a panel cointegration test, but the results reject this hypothesis. Rather, the heterogeneity of the ERPT is explained mainly by such macroeconomic determinants as exchange rate regimes, inflation regimes, and trade barriers. Baharumshah, Soon, and Wohar (2017) apply a Markov-switching model with time-series data to test the nonlinear characteristics of the passthrough from exchange rates to domestic prices. They find that the ERPT is incomplete and lower for a stable period in both the short and long run for most countries and that the degree of ERPT is more sensitive in a high inflation environment. In the same vain, Kiliç (2015) shows evidence of threshold effects in the ERPT in six developed countries using logistic smooth transition passthrough regression. Two threshold regimes are documented, the first with low pass-through and the second with high pass-through. However, using a single equation in these studies is limited in that it does not take into account the causal relationship between inflation and the exchange rate (Jiang and Kim 2013).

The second method uses multiple estimation equations with a vector auto-regressive (VAR) model in combination with IRFs. The VAR has several advantages over the single-equation 
approach. First, it allows the consideration of dynamic feedback between inflation and the exchange rate. Second, it provides an integrated model in which the impact of the exchange rate and monetary policy shocks on price levels can be examined simultaneously. Third, the VAR makes it possible for the ERPT to domestic prices to be tracked in order of a chain of distribution.

Various studies have adopted a VAR approach to investigate the degree of ERPT to domestic prices in both advanced and emerging countries (Jiang and Kim 2013; Jiménez-Rodríguez and Morales-Zumaquero 2016; Hájek and Horváth 2016; McCarthy 2007; Saha and Zhang 2013, 2016). However, in this paper, we provide a summary of analyses in Asia. To begin with, using an SVAR model, Ito and Sato (2008) examine the degree of ERPT in domestic prices in the five Asian countries that suffered most in the Asian financial crisis (1997): Indonesia, South Korea, Malaysia, Singapore, and Thailand. Their results indicate that, first, the degree of ERPT is much higher into import prices than into producer prices, and it is found to be low for consumer prices, and, second, monetary variables have a positively significant and large impact on consumer prices in Indonesia, which has experienced high inflation and currency depreciation since the Asian financial crisis. Another analysis of ERPT in Asia is conducted by Cortinhas (2009), who examines five ASEAN members: Indonesia, Malaysia, the Philippines, Singapore, and Thailand. Using a recursive VAR model and the Cholesky decomposition technique on each pair of countries, Cortinhas shows that groups of three of these countries, such as Malaysia, Singapore, and Thailand, could enter a currency union, because their exchange rates are disconnected. In addition, Indonesia could join this union for a different reason: the shocks of an independent monetary policy to its economy would be eliminated. The Philippines appears to have a weaker case for joining because of a statistically significant ERPT to consumer prices, but not import prices, there. 
VAR models are widely used in research. Stock and Watson (2001), for example, examine three kinds of VAR models: reduced-form VAR, recursive VAR, and structural VAR (SVAR). In a reduced-form VAR model, every single variable is regressed by its own lags and those of all other variables. The problem with this is that the error terms or residuals might be correlated among equations and includes a stochastically contemporaneous effect among variables. Hence, the reduced-form VAR model cannot be employed to interpret an economically causal relation among variables. The recursive VAR model contributes to the problem of correlated error terms by ordering all influential variables to eliminate the correlation of the error term with the preceding equation. For example, the first equation explores the first-order variable as a dependent variable and its own lags as explanatory variables; the second equation includes the second-order variable as the dependent variable and its own lag as well as the present value of the first-order variable. This raises a new question about how to identify the order of the variables included. Using an SVAR model can resolve this problem. As mentioned by Stock and Watson (2001), the "identifying assumptions" become the strictest assumption in a VAR model. The assumption requires economic theory to support the sorting of variables in order of influence. Therefore, an SVAR model is widely adopted to interpret the causal relationship among endogenous variables. The advantages of an SVAR model lead economists to use it for identifying complicated relationships among endogenous variables in their models.

In summary, the magnitude and speed of ERPT vary considerably across ASEAN members in different studies (Cortinhas 2009; Ito and Sato 2008). The inconsistent findings may result from the data constraints. Therefore, the degree of ERPT to domestic prices, especially among ASEAN members with the application of a new dataset and a more appropriate method, remains an open question. 


\section{An Analytical Framework}

In modeling ERPT to domestic prices, including the producer price index (PPI) and the consumer price index (CPI), we rely on McCarthy's (2007) study, in which the model of pricing along a distribution chain is applied. The rate of inflation or the change in domestic prices has several components. The first component is the expected value based on the previous period including all available information. The second consists of the effect of domestic supply and demand shocks as well as exchange rate shocks on the inflation rate of domestic prices at the current stage. Third are the effects from current and previous shocks in a distribution chain. To be more specific, the inflation rate in the PPI and the CPI in a country can be expressed as follows:

$\pi_{t}^{p p i}=f\left(E_{t-1}\left(\pi_{t}^{p p i}\right), \varepsilon_{t}^{s}, \varepsilon_{t}^{d}, \varepsilon_{t}^{e}, \varepsilon_{t}^{p p i}\right)$

$\pi_{t}^{c p i}=f\left(E_{t-1}\left(\pi_{t}^{c p i}\right), \varepsilon_{t}^{S}, \varepsilon_{t}^{d}, \varepsilon_{t}^{e}, \varepsilon_{t}^{p p i}, \varepsilon_{t}^{c p i}\right)$

where $\pi_{t}^{p p i}$ and $\pi_{t}^{c p i}$ represent the inflation rate in the PPI and the CPI, respectively, while $\varepsilon_{t}^{S}, \varepsilon_{t}^{d}$, and $\varepsilon_{t}^{e}$ are the shocks from supply, demand, and the exchange rate. $\varepsilon_{t}^{p p i}$ and $\varepsilon_{t}^{c p i}$ are the

shocks to themselves from the PPI and the CPI at the current stage, while $E_{t-1}\left(\pi_{t}^{p p i}\right)$ and $E_{t-1}\left(\pi_{t}^{c p i}\right)$ shows their own shocks at a previous stage.

To fully develop the model, we make some assumptions to identify the shocks from aggregated supply and demand as well as the exchange rate. The supply shocks are indicated by the inflation rate or oil prices, whereas shocks from the demand side are referred to output gaps, the difference between a country's gross domestic product (GDP) and its potential level. The exchange rate shocks are identified from changes in the exchange rate.

Monetary policy influences the fluctuation in the exchange rate and output, so we also add this variable to the model. The interest rate is a proxy for monetary policy because the central bank 
in a country often uses it as a tool for market intervention. Also, we use the bilateral exchange rate, rather than the nominal exchange rate, to examine the pass-through to domestic prices. The principal argument for using the bilateral exchange rate vis-à-vis the US dollar is that the dollar is highly likely to be the dominant currency in the region, accounting for a large portion of the foreign exchange reserves, regional payments, and financial transactions (Volz 2014). The US dollar also accounts for a significant amount of invoice payments in most ASEAN member countries.

Like Ito and Sato (2008) and Saha and Zhang (2013, 2016), we use a modified model to investigate the ERPT to the PPI and the CPI using an SVAR model. Six endogenous variables are adopted in the model, including the international oil price (oilp), the output gap (ygap), the interest rate (intr), the bilateral exchange rate with the US dollar (er), the PPI (ppi), and the CPI (cpi). These domestic prices are employed to examine macroeconomic stability. Therefore, the model is a vector of six variables as follows:

$$
X_{t}=\Delta o i l_{t}, \Delta i n t r_{t}, \operatorname{ygap}_{t}, \Delta e r_{t}, \Delta p p i_{t}, \Delta c p i_{t} .
$$

The subscript is the variable of interest in the logarithm, and $\Delta$ indicates the data in first difference. The output gap is calculated using the Hodrick-Prescott (HP) filter method, the interest rate represents the annual lending rate, and the oil price is in terms of USD per barrel. The standard VAR model is specified as follows:

$$
X_{t}=\varnothing+\prod_{1} X_{t-1}+\prod_{2} X_{t-2}+\ldots+\prod_{k} X_{t-k}+\mu_{t},
$$

where $X_{t}$ is the vector of endogenous variables; $\mu_{t}$ is a vector of innovations that may be contemporaneously correlated, but uncorrelated with their own lagged values and variables on the right-hand side. $\emptyset$ is a vector of constants, and $\prod_{i}$ are matrices of coefficients to be estimated.

The Cholesky decomposition encompasses the decomposition of the variance-covariance matrix $\Omega$ of the reduced-form residuals in a lower triangular matrix $\mathrm{S}$. The matrix $\mathrm{S}$ imposes $k(k-$ 
1)/2 restrictions as zero so that the identified structural shocks from the variables at an early stage do not simultaneously influence those ordered later. The reduced-formed VAR residuals $\left(\mu_{t}\right)$ and the structural shocks $\left(\varepsilon_{t}\right)$ can be specified as follows:

$$
\left[\begin{array}{c}
\mu_{t}^{\text {oil }} \\
\mu_{t}^{\text {inrt }} \\
\mu_{t}^{\text {ygap }} \\
\mu_{t}^{\text {er }} \\
\mu_{t}^{\text {ppi }} \\
\mu_{t}^{c p i}
\end{array}\right]=\left[\begin{array}{cccccc}
S_{11} & 0 & 0 & 0 & 0 & 0 \\
S_{21} & S_{22} & 0 & 0 & 0 & 0 \\
S_{31} & S_{32} & S_{33} & 0 & 0 & 0 \\
S_{41} & S_{42} & S_{43} & S_{44} & 0 & 0 \\
S_{51} & S_{52} & S_{53} & S_{54} & S_{55} & 0 \\
S_{61} & S_{62} & S_{63} & S_{64} & S_{65} & S_{66}
\end{array}\right]\left[\begin{array}{c}
\varepsilon_{t}^{\text {oil }} \\
\varepsilon_{t}^{\text {inrt }} \\
\varepsilon_{t}^{\text {ygap }} \\
\varepsilon_{t}^{\text {er }} \\
\varepsilon_{t}^{p p i} \\
\varepsilon_{t}^{c p i}
\end{array}\right]
$$

Identification of the structural shock $\left(\varepsilon_{t}\right)$ is obtained by appropriately ordering the six variables of interest and applying Cholesky decomposition to the variance matrix of the reducedform residuals $\left(\mu_{t}\right)$. In this sense, it is important to set the order of the variables. The oil price, inflation rate, and output gap indicate the state of an economy, while the interest rate reflects monetary policy. The oil price shock is ordered first, as no factor affects the oil price in a country except for its own supply, and it influences other variables (Ito and Sato 2008). Following an oil price shock, change in the interest rate captures monetary shocks. Ordering monetary policy shock second allows it to affect the exchange rate and the output in a country (Saha and Zhang 2013, 2016). Next, the exchange rate shock is set after the output gap so that it can respond to the demand shock. Finally, we follow the literature on distribution chains to put the price levels last in the order.

\section{Data and Empirical Results}

\subsection{Data}

This study uses up-to-date quarterly data collected from a variety of sources until 2016. The timeframe for Malaysia and Singapore begins in 1990:Q1 and that for Indonesia, the Philippines, and Thailand starts in 1993:Q1, although data for Indonesia end in 2012:Q4 because of their 
unavailability. The oil price in terms of the US dollar comes from the Federal Reserve Bank of St. Louis, and quarterly data on the interest rate, output, bilateral exchange rate, the PPI, and the CPI for each country come from the International Monetary Fund's International Financial Statistics, the Bank of Thailand, the Department of Statistics in Malaysia, and Indonesia's Central Bureau of Statistics. In this study, the bilateral exchange rate is defined as the amount of domestic currency per one US dollar, that is, that an upward trend in an exchange rate means depreciation of a country's currency. See Appendix 2 for a statistical description of variables included in this study.

\subsection{Empirical Results}

In constructing an SVAR model, the initial procedure is checking whether all variables of interest are stationary. The study adopts the two commonly used tests, the augmented Dickey-Fuller (ADF) test and the Phillips-Perron (PP) test. We use a lag length of 2 for all estimations and report the results in terms of both levels and first differences in Table 1. Most variables contain unit roots at levels except for the output gap, but they are stationary at the first difference. Thus, we conclude that the output gap is integrated at $\mathrm{I}(0)$ while other variables are $\mathrm{I}(1)$. As such, the SVAR model is considered a proper approach. Using an SVAR model allows us to concentrate on the ERPT dynamics into domestic prices in five ASEAN member countries in a distribution chain.

\section{[Table 1]}

The next procedure in building the SVAR model is designing the baseline models and then analyzing the IRFs of the variables. The optimal lag length of 1 is used in this paper on the basis of Akaike information criteria (AIC). Figure 1 shows the exchange rate shock and its effects on the PPI and the CPI in the five countries. Four of the countries-Indonesia, Malaysia, the Philippines, and Thailand - experience the same response pattern, in which the response is positive in the first quarter, has a downward trend in the next quarter, and dissipates during the last two 
quarters. In contrast, in Singapore, a negative effect from the exchange rate shock on producer prices is observed in the first quarter and remains unchanged in the last three quarters. Exchange rate shocks have no effect on consumer prices in Malaysia, the Philippines, and Thailand. The CPI response is found to be positive in Indonesia but significantly negative in Singapore. It is possible that depreciation of the Singapore dollar will help Singapore to increase exports. Given a strict contractionary monetary policy by the Monetary Authority of Singapore, the overall effect is that the depreciation of the Singapore dollar helps control inflation.

\section{[Figure 1]}

Based on the IRFs, dynamic EPRT elasticity is calculated by dividing cumulative changes in each price index in response to exchange rate shocks by cumulative changes in the exchange rate to its own shocks. ${ }^{3}$ The equation for calculating elasticity is as follows:

$$
P T_{t, t+j}=\sum_{j=1}^{t} \hat{P}_{t, t+j} / \sum_{j=1}^{t} \hat{E}_{t, t+j}
$$

in which $\hat{P}_{t, t+j}$ is the cumulative changes in each price index in response to exchange rate shocks after $j$ quarter, and $\hat{E}_{t, t+j}$ is the cumulative changes in the exchange rate in response to its own shocks after $j$ quarter. The dynamic ERPT coefficient $P T_{t, t+j}$ indicates the cumulative response of the price changes to exchange rate shocks, nominalized by the corresponding response of the exchange rate. The negative pass-through implies that depreciation of the country's currency against the US dollar causes a decline in prices. Table 2 shows the ERPT elasticity for both producer and consumer prices in the five countries over a two-year period.

\section{[Table 2]}

\footnotetext{
${ }^{3}$ This method has been employed in a few previous studies (Ito and Sato 2008; Saha and Zhang 2016).
} 
Table 2 indicates that, although all five countries have evidence of incomplete pass-through, the degree of ERPT is found to be much higher to the PPI than to the CPI. Specifically, Indonesia experiences the largest ERPT to both producer (0.56) and consumer prices $(0.35)$ in the first quarter, and this gradually increases over the coming quarters, meaning that changes in the exchange rate would be reflected in the inflation rate over time. The Philippines and Thailand seem to have a similar pattern of ERPT to domestic prices, though it is higher in the Philippines. The degree of pass-through for PPI varies between 0.13 and 0.18 , whereas the coefficients for CPI are from zero to 0.03 . In Malaysia, the ERPT to producer prices increases from 0.08 in the first quarter to 0.14 within two years, whereas consumer prices for the same period remain unchanged at 0.02 . Although Singapore has low ERPT elasticity in terms of producer prices, its elasticity in terms of consumer prices is consistently negative.

Next, we analyze how fluctuations in domestic prices are explained by their variance and those of other variables. Table 3 shows the results of variance decomposition for producer prices in the five ASEAN member countries. The oil price, output gap, and the PPI itself are largely attributed to changes in the PPI. In Indonesia, the variance in producer prices is significantly explained by the output gap and the exchange rate ( $47 \%$ for the output gap and $25 \%$ for the exchange rate, respectively) in the first two quarters. Following the oil price, the interest rate plays a moderate role in explaining changes in the variance in the PPI, making up only about $5 \%$. In the four other countries, besides the PPI itself, an external factor represented by the oil price accounts for a large percentage of the variance in consumer prices, as much as $70 \%$ in Singapore, $40 \%$ in Malaysia and Thailand, and 30\% in the Philippines. The output gap shock is the next factor explaining changes in producer prices in Malaysia, while bilateral exchange rate shocks are the next indicator in the Philippines, Singapore, and Thailand. In these three countries, the interest 
rate, output gap, and bilateral exchange rate make up a minute proportion of the variance in producer prices.

\section{[Table 3]}

Table 4 shows the variance decomposition of the CPI. In general, the impacts of shocks on consumer prices, unlike those on producer prices, in these five countries differ significantly. Specifically, changes in the inflation rate in Indonesia are driven mainly by the output gap and exchange rate shocks, comprising nearly $30 \%$ after a year, followed by the interest rate and producer prices, with a total variance of approximately $20 \%$. The inflation rate is modestly affected by its own shocks, with variance of less than 20 percent. In contrast, in Malaysia, the Philippines, and Thailand, the inflation rate is explained mainly by its own shocks, comprising more than 70 percent in all three countries, followed by oil price shocks, which account for 10 percent, 8 percent, and 20 percent, respectively, over the two-year period. Producer prices and the output gap also play a considerable role in explaining changes in the inflation rate in Malaysia and the Philippines. In Thailand, the oil price and producer price shocks are the next-most-important indicator in accounting for the variance in consumer prices, after their own shocks.

\section{[Table 4]}

The variance composition has some interesting implications. First, in addition to their own shocks, external factors explain the modest changes in both producer and consumer prices, in most of the countries, except for Indonesia, where the domestic prices are mainly affected by the output gap and exchange rate shocks. Second, producer prices appear to have a moderate impact on consumer prices in Indonesia, Malaysia, and Thailand, but there is no reverse impact in all cases. Third, monetary policy proxied by the interest rate plays a minuscule role in explaining the variance in domestic prices. 


\subsection{Discussions and Robustness Tests}

On average, ERPT has effects on domestic price indices. In particular, the pass-through effects of the exchange rate are relatively higher to the PPI than to the CPI. The result seems to be consistent with international economic theory, which indicates that multinational corporations wishing to enter a particular country usually quote their selling price in the local currency in order to minimize their exposure to exchange rate volatility. Empirically, a similar result reported in Ito and Sato's (2008) analysis supports our arguments, in which the magnitude of the pass-through effect is much larger to the PPI than to the CPI.

Cortinhas (2009) supports the formation of a currency union involving Singapore, Thailand, and Malaysia because of their insignificant interactions between exchange rates and both domestic inflation and import prices. Our study has similar results except for Singapore. In Malaysia and Thailand, the responses of the CPI, representing domestic inflation to exchange rate changes, are all below 0.02 , which means $10 \%$ appreciation in the nominal effective exchange rate results in changes in the CPI of less than 2\%. However, this phenomenon does not exist in Singapore, where the absolute responses are from 0.07 to 0.12 , which means a relatively high response by domestic inflation to exchange rate shocks. The difference between Cortinhas (2009) and our results is in the difference in the periods studied and how they are measured. In fact, our study ignores the role of ERPT in supporting a currency union, and this could be a potential subject of further research.

The degree of the output gap and exchange rate shocks that contribute to the variance decomposition of price levels in Indonesia is noteworthy. It can be explained by the fact that the 1997-98 Asian financial crisis had such a severe impact on the country that it led to a domestic financial crisis and internal political instability and eventually caused a decline on the supply side of the economy. The crisis resulted in the closure of a number of insolvent banks, driving 
depositors to leave the country, and thus the domestic banking system fell into a liquidity shortage. The central bank, Indonesia Bank, faced a severe dilemma regarding monetary policy, in seeking a way to keep the rupiah's exchange rate from depreciating while trying to tame the inflation rate, which was continuing to rise. Indonesia Bank had issued SBI, a central bank certificate, to increase the interest rate and limit the currency depreciation. At the same time, Indonesia Bank played a role as a lender of last resort by expanding base money growth with a huge injection of liquidity. These actions were taken to keep banks afloat, stabilize the financial system, and boost the economy, but had the side effect of raising the inflation rate.

In order to test the sensitivity of the results, we perform a set of robustness checks. In the base model, the interest rate precedes the output gap, implying that monetary shocks influence a country's exchange rate and output. Moreover, monetary policy is supposed to respond to domestic economic conditions, so the output gap should precede the monetary policy variable. Additionally, information regarding real output growth becomes available after a period of time (Ito and Sato, 2008). Thus, an alternative order in the model is: the oil price, the output gap, the interest rate, the bilateral exchange rate, the PPI, and the CPI. We find that the response of the price indexes, both the PPI and CPI, to changes in the exchange rate in this alternative is almost the same. The results are not reported in this paper but are available upon request.

\section{Concluding remarks}

This paper attempts to reinvestigate the degree of pass-through from the exchange rate into domestic producer and consumer prices. In an open economy, these two types of indices play an extremely crucial role in the macroeconomic policy with respect to price stability. The study uses five member countries of ASEAN-Indonesia, Malaysia, the Philippines, Singapore, and Thailand - where all the data required for this analysis are available and updated to 2016 . We 
adopt an SVAR model for our research purposes because the technique has enormous advantages in comparison with an approach using a single equation or other forms of VAR.

Several interesting findings emerge from our study. First, incomplete ERPT to domestic prices is seen in all the countries in the sample during the research period, though producer prices are found to be affected more than consumer prices. Second, exchange rate shocks are found to have an immediate effect on domestic prices. The effect on producer prices lasts for a quarter for all countries before dissipating gradually in all countries. The effect on consumer prices persists for two quarters and gradually disappears in next two quarters in Indonesia and Singapore, while no effect on consumer prices is seen in the three other countries. Third, the variance in domestic prices is found to be caused mainly by shocks from oil prices, output gaps, and exchange rates, while the extent of effects across the countries varies. Fourth, the monetary policy variable, proxied by the interest rate, plays a minor role in affecting domestic prices, especially the inflation rate. As such, policy makers are in pursuit of price stability in their economy, so exchange rate policy as well as interest rate policy should be considered with caution. Another indispensable indicator of monetary policy is the money supply, which should be taken into consideration. Doing so would offer a more complete understanding of how exchange rate pass-through affects domestic prices and would lead to more informed policy suggestions, so it would be a useful direction for future research.

\section{References}

Alvarez, R., P. Jaramillo, and J. Selaive. 2012.“Is the Exchange Rate Pass-Through into Import Prices Declining? Evidence from Chile.” Emerging Markets Finance and Trade 48 (1): 100116. 
Baharumshah, A.Z., S.V. Soon, and M.E. Wohar. 2017. "Markov-Switching Analysis of Exchange Rate Pass-Through: Perspective from Asian Countries.” International Review of Economics and Finance 51: 245-57.

Barhoumi, K. 2006. “Differences in Long Run Exchange Rate Pass-Through into Import Prices in Developing Countries: An Empirical Investigation.” Economic Modelling 23 (6): 926-51.

Campa, J. M., and L. S. Goldberg. 2005. "Exchange Rate Pass-Through into Import Prices." Review of Economics and Statistics 87 (4): 679-90.

Choudhri, E.U., and D.S. Hakura. 2006. "Exchange Rate Pass-Through to Domestic Prices: Does the Inflationary Environment Matter?’ Journal of International Money and Finance 25 (4): $614-39$.

_ 2014. "The Exchange Rate Pass-Through to Import and Export Prices: The Role of Nominal Rigidities and Currency Choice." Journal of International Money and Finance 51: $1-25$.

Cortinhas, C. 2009. "Exchange Rate Pass-Through in ASEAN: Implications for the Prospects of Monetary Integration in the Region." Singapore Economic Review 54 (4): 657-87.

Ghosh, A. 2013. “Exchange Rate Pass Through, Macro Fundamentals and Regime Choice in Latin America." Journal of Macroeconomics 35 (1): 163-71.

Ghosh, A., and R.S. Rajan. 2009a. "What Is the Extent of Exchange Rate Pass-Through in Singapore? Has It Changed over Time?" Journal of the Asia Pacific Economy 14 (1): 61-72. _ 2009b. "Exchange Rate Pass-Through in Korea and Thailand: Trends and Determinants." Japan and the World Economy 21 (1): 55-70. 
Hájek, J., and R. Horváth. 2016. "Exchange Rate Pass-Through in an Emerging Market: The Case of the Czech Republic." Emerging Markets Finance \& Trade 52 (11): 2624-35.

Ito, T., and K. Sato. 2008. "Exchange Rate Changes and Inflation in Post-Crisis Asian Economies: Vector Autoregression Analysis of the Exchange Rate Pass-Through.” Journal of Money, Credit and Banking 40 (7): 1407-38.

Jiang, J., and D. Kim. 2013. "Exchange Rate Pass-Through to Inflation in China." Economic Modelling 33: 900-912.

Jiménez-Rodríguez, R., and A. Morales-Zumaquero. 2016. “A New Look at Exchange Rate PassThrough in the G-7 Countries." Journal of Policy Modeling 38 (5): 985-1000.

Kiliç, R. 2015. "Regime Dependent Exchange Rate Pass-Through to Import Prices.” International Review of Economics and Finance 41: 295-308.

McCarthy, J. 2007. "Pass-Through of Exchange Rates and Import Prices to Domestic Inflation in Some Industrialized Economies.” Eastern Economic Journal 33 (4): 511-37.

Parsons, C.R., and K. Sato. 2006. "Exchange Rate Pass-Through and Currency Invoicing: Implications for Monetary Integration in East Asia." World Economy 29 (12): 1759-88.

Prasertnukul, W., D. Kim, and M. Kakinaka. 2010. "Exchange Rates, Price Levels, and Inflation Targeting: Evidence from Asian Countries.” Japan and the World Economy 22 (3): 173-82.

Saha, S., and Z. Zhang. 2013. "Do Exchange Rates Affect Consumer Prices? A Comparative Analysis for Australia, China and India." Mathematics and Computers in Simulation 93: 12838. 
_ 2016. "Exchange Rate Pass-Through and Its Impact on Inflation: A Comparative Study for Australia, China and India with Disaggregated Data.” Journal of Economic Research 21 (1): $1-33$.

Soon, S., and A.Z. Baharumshah. 2017. "Exchange Rate Pass-through (ERPT) into Domestic Prices: Evidence from a Nonlinear Perspective," Economics Bulletin 37 (2): 1160-67.

Stock, J. H. and M. W. Watson. 2001. "Vector Autoregressions." Journal of Economic Perspectives 15 (4): 101-15.

Toh, M., and H. Ho. 2001. "Exchange Rate Pass-Through for Selected Asian Economies." Singapore Economic Review 46 (2): 247-73.

Volz, U. 2014. "RMB Internationalisation and Currency Cooperation in East Asia.” In Currency Cooperation in East Asia, 57-81. Cham: Springer.

Webber, A.G. 1999. "Dynamic and Long Run Responses of Import Prices to the Exchange Rate in the Asia-Pacific.” Asian Economic Journal 13 (3): 303-20.

Zhang T., and Y. Li. 2017. "Incomplete Exchange Rate Pass-Through: Evidence from Exchange Rate Reform in China." Emerging Markets Finance and Trade 53 (3): 710-26. 
Table 1. Results of unit-root tests

\begin{tabular}{|c|c|c|c|c|c|}
\hline Variable & Indonesia & Malaysia & Philippines & Singapore & Thailand \\
\hline \multicolumn{6}{|c|}{ Panel A: ADF Test Statistics } \\
\hline ygap & $-3.21 *$ & $-3.46 * *$ & $-7.62 * * *$ & $-3.81 * *$ & $-3.52 * *$ \\
\hline oilp & -2.66 & -1.89 & -1.58 & -1.98 & -1.58 \\
\hline$\Delta$ oilp & $-7.90 * * *$ & $-8.89 * * *$ & $-7.81 * * *$ & $-8.92 * * *$ & $-7.81 * * *$ \\
\hline intr & -1.88 & -2.28 & -3.02 & -2.38 & -1.04 \\
\hline$\Delta$ intr & $-4.88 * * *$ & $-5.82 * * *$ & $-8.04 * * *$ & $-7.22 * * *$ & $-4.83 * * *$ \\
\hline er & -1.27 & -1.36 & -1.30 & -1.38 & -1.59 \\
\hline$\Delta$ er & $-7.69 * * *$ & $-6.68 * * *$ & $-6.18 * * *$ & $-8.10 * * *$ & $-6.75 * * *$ \\
\hline ppi & -1.31 & -0.86 & 1.48 & -1.86 & -1.00 \\
\hline$\Delta$ ppi & $-6.55 * * *$ & $-6.82 * * *$ & $-6.34 * * *$ & $-8.83 * * *$ & $-7.85 * * *$ \\
\hline cpi & -0.35 & -2.42 & -1.77 & -0.94 & -1.65 \\
\hline$\Delta \mathrm{cpi}$ & $-4.63 * * *$ & $-8.72 * * *$ & $-6.96 * * *$ & $-6.01 * * *$ & $-6.42 * * *$ \\
\hline \multicolumn{6}{|c|}{ Panel B: Phillips-Perron Test Statistics } \\
\hline ygap & $-3.69 * *$ & $-3.91 * *$ & $-7.82 * * *$ & $-4.06 * * *$ & $-3.78 * *$ \\
\hline oilp & -2.75 & -2.09 & -1.88 & -2.18 & -1.88 \\
\hline$\Delta$ oilp & $-7.82 * * *$ & $-8.24 * * *$ & $-7.12 * * *$ & $-8.86 * * *$ & $-7.12 * * *$ \\
\hline intr & -2.62 & -2.76 & $-3.43^{*}$ & -2.98 & -1.65 \\
\hline$\Delta$ intr & $-5.02 * * *$ & $-5.84 * * *$ & $-7.93 * * *$ & $-7.09 * * *$ & $-4.91 * * *$ \\
\hline er & -1.63 & -1.82 & -1.54 & -1.64 & -1.81 \\
\hline$\Delta$ er & $-7.73 * * *$ & $-6.12 * * *$ & $-6.19 * * *$ & $-8.10 * * *$ & $-6.69 * * *$ \\
\hline ppi & -1.86 & -1.40 & 1.11 & -2.00 & -1.19 \\
\hline$\Delta \mathrm{ppi}$ & $-6.58 * * *$ & $-6.59 * * *$ & $-6.38 * * *$ & $-8.73 * * *$ & $-7.74 * * *$ \\
\hline cpi & -1.21 & -2.40 & -1.81 & -1.44 & -1.79 \\
\hline$\Delta \mathrm{cpi}$ & $-4.73 * * *$ & $-8.63 * * *$ & $-7.05 * * *$ & $-6.18 * * *$ & $-6.24 * * *$ \\
\hline
\end{tabular}

Notes: The critical values for significance levels of $1 \%, 5 \%$, and $10 \%$ are $-4.05,-3.45$, and -3.15 respectively. $* * *, * *$, and $*$ indicate significance at the $1 \%, 5 \%$, and $10 \%$ levels, respectively. 
Table 2. Exchange rate pass-through to domestic prices

\begin{tabular}{lcccccc}
\hline Country & Price Index & $\mathrm{t}=1$ & $\mathrm{t}=2$ & $\mathrm{t}=4$ & $\mathrm{t}=6$ & $\mathrm{t}=8$ \\
\hline Indonesia & PPI & 0.56 & 0.55 & 0.54 & 0.57 & 0.59 \\
Malaysia & CPI & 0.35 & 0.40 & 0.44 & 0.48 & 0.52 \\
& PPI & 0.08 & 0.08 & 0.10 & 0.13 & 0.14 \\
Philippines & CPI & 0.02 & 0.02 & 0.02 & 0.02 & 0.02 \\
& PPI & 0.18 & 0.17 & 0.15 & 0.14 & 0.14 \\
Singapore & CPI & 0.01 & 0.02 & 0.01 & 0.01 & 0.01 \\
& PPI & 0.06 & 0.03 & 0.04 & 0.03 & 0.03 \\
Thailand & CPI & -0.07 & -0.10 & -0.12 & -0.12 & -0.12 \\
& PPI & 0.17 & 0.16 & 0.15 & 0.14 & 0.13 \\
& CPI & 0.03 & 0.03 & 0.03 & 0.01 & 0.00 \\
\hline
\end{tabular}

Notes: PPI = Producer Price Index. CPI = Consumer Price Index 
Table 3. A Decomposition of Variance in the Producer Price Index (PPI)

\begin{tabular}{|c|c|c|c|c|c|c|}
\hline Period & Oil price & Interest rate & Output gap & Exchange rate & PPI & $\mathrm{CPI}$ \\
\hline \multicolumn{7}{|c|}{ Indonesia } \\
\hline 0 & 0 & 0 & 0 & 0 & 100 & 0 \\
\hline 2 & 8.20 & 2.48 & 47.83 & 25.73 & 14.88 & 0.88 \\
\hline 4 & 8.26 & 4.21 & 46.95 & 24.88 & 14.34 & 1.37 \\
\hline 6 & 8.43 & 4.17 & 47.80 & 24.23 & 14.00 & 1.37 \\
\hline 8 & 8.44 & 4.41 & 47.98 & 23.96 & 13.83 & 1.38 \\
\hline \multicolumn{7}{|c|}{ Malaysia } \\
\hline 0 & 0 & 0 & 0 & 0 & 100 & 0 \\
\hline 2 & 39.24 & 0.42 & 13.71 & 1.00 & 39.76 & 5.86 \\
\hline 4 & 38.86 & 0.68 & 13.32 & 0.99 & 38.58 & 7.58 \\
\hline 6 & 38.88 & 0.68 & 13.33 & 0.99 & 38.55 & 7.57 \\
\hline 8 & 38.88 & 0.68 & 13.33 & 1.00 & 38.54 & 7.58 \\
\hline \multicolumn{7}{|c|}{ Philippines } \\
\hline 0 & 0 & 0 & 0 & 0 & 100 & 0 \\
\hline 2 & 30.30 & 1.35 & 2.23 & 6.77 & 57.53 & 1.82 \\
\hline 4 & 32.16 & 1.42 & 2.51 & 6.57 & 54.73 & 2.61 \\
\hline 6 & 32.13 & 1.43 & 2.51 & 6.66 & 54.66 & 2.62 \\
\hline 8 & 32.13 & 1.43 & 2.51 & 6.66 & 54.65 & 2.62 \\
\hline \multicolumn{7}{|c|}{ Singapore } \\
\hline 0 & 0 & 0 & 0 & 0 & 100 & 0 \\
\hline 2 & 72.59 & 0.32 & 0.08 & 3.33 & 23.61 & 0.07 \\
\hline 4 & 71.52 & 0.75 & 1.22 & 3.28 & 23.15 & 0.08 \\
\hline 6 & 71.43 & 0.76 & 1.45 & 3.26 & 23.02 & 0.08 \\
\hline 8 & 71.41 & 0.77 & 1.50 & 3.25 & 22.99 & 0.08 \\
\hline \multicolumn{7}{|c|}{ Thailand } \\
\hline 0 & 0 & 0 & 0 & 0 & 100 & 0 \\
\hline 2 & 41.06 & 1.01 & 2.49 & 4.04 & 51.00 & 0.40 \\
\hline 4 & 40.32 & 1.00 & 4.59 & 3.95 & 49.58 & 0.55 \\
\hline 6 & 39.80 & 1.04 & 5.75 & 3.98 & 48.88 & 0.55 \\
\hline 8 & 39.69 & 1.07 & 5.95 & 4.00 & 48.73 & 0.56 \\
\hline
\end{tabular}


Table 4. Decomposition of Variance in the Consumer Price Index (CPI)

\begin{tabular}{|c|c|c|c|c|c|c|}
\hline Period & Oil price & Interest rate & Output gap & Exchange rate & PPI & $\mathrm{CPI}$ \\
\hline \multicolumn{7}{|c|}{ Indonesia } \\
\hline 0 & 0 & 0 & 0 & 0 & 0 & 100 \\
\hline 2 & 0.34 & 4.79 & 34.25 & 29.90 & 10.07 & 20.65 \\
\hline 4 & 0.42 & 11.05 & 34.63 & 27.66 & 8.67 & 17.56 \\
\hline 6 & 0.96 & 11.72 & 34.62 & 27.15 & 8.53 & 17.02 \\
\hline 8 & 1.37 & 11.52 & 35.63 & 26.50 & 8.36 & 16.63 \\
\hline \multicolumn{7}{|c|}{ Malaysia } \\
\hline 0 & 0 & 0 & 0 & 0 & 0 & 100 \\
\hline 2 & 10.16 & 0.07 & 4.64 & 0.88 & 7.81 & 76.45 \\
\hline 4 & 12.56 & 0.21 & 4.50 & 0.90 & 8.02 & 73.80 \\
\hline 6 & 12.59 & 0.24 & 4.53 & 0.96 & 8.00 & 73.67 \\
\hline 8 & 12.59 & 0.25 & 4.54 & 0.96 & 8.00 & 73.66 \\
\hline \multicolumn{7}{|c|}{ Philippines } \\
\hline 0 & 0 & 0 & 0 & 0 & 0 & 100 \\
\hline 2 & 6.38 & 0.75 & 8.85 & 2.71 & 1.27 & 80.04 \\
\hline 4 & 8.18 & 0.94 & 9.65 & 3.01 & 1.22 & 77.00 \\
\hline 6 & 8.23 & 0.94 & 9.67 & 3.06 & 1.22 & 76.88 \\
\hline 8 & 8.23 & 0.94 & 9.67 & 3.06 & 1.22 & 76.87 \\
\hline \multicolumn{7}{|c|}{ Singapore } \\
\hline 0 & 0 & 0 & 0 & 0 & 0 & 100 \\
\hline 2 & 15.70 & 0.91 & 3.30 & 3.28 & 1.03 & 75.77 \\
\hline 4 & 20.21 & 1.21 & 3.20 & 4.54 & 0.93 & 69.92 \\
\hline 6 & 20.17 & 1.32 & 3.29 & 4.57 & 0.93 & 69.72 \\
\hline 8 & 20.17 & 1.32 & 3.34 & 4.57 & 0.93 & 69.67 \\
\hline \multicolumn{7}{|c|}{ Thailand } \\
\hline 0 & 0 & 0 & 0 & 0 & 0 & 100 \\
\hline 2 & 32.27 & 1.54 & 1.24 & 0.65 & 26.06 & 38.24 \\
\hline 4 & 31.15 & 1.79 & 4.94 & 0.67 & 24.77 & 36.68 \\
\hline 6 & 30.34 & 1.76 & 7.79 & 0.78 & 23.91 & 35.41 \\
\hline 8 & 30.07 & 1.80 & 8.53 & 0.87 & 23.67 & 35.06 \\
\hline
\end{tabular}


Figure 1. Impulse response of price levels to bilateral exchange rate shocks

a) Impulse response of the PPI
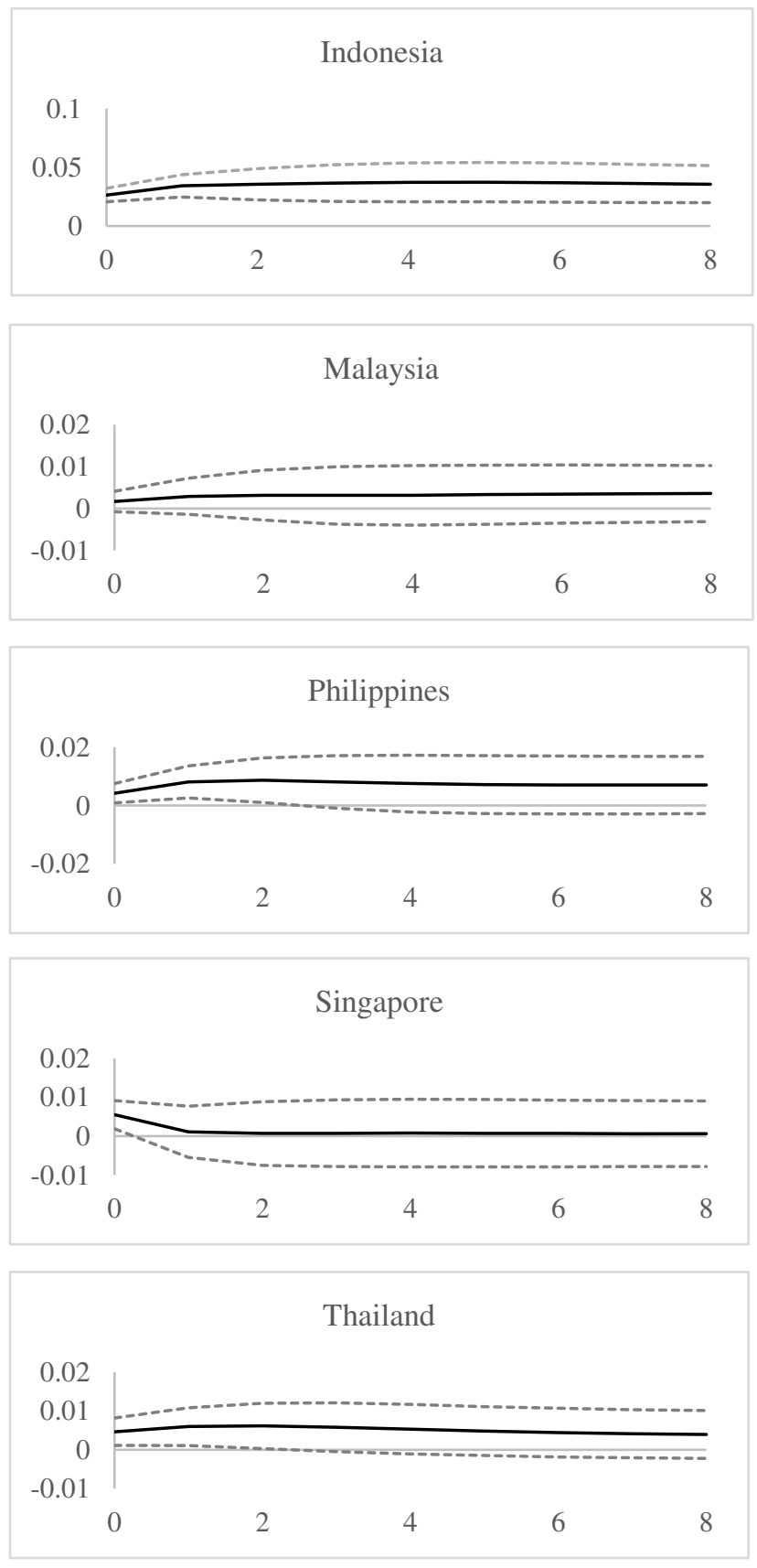

b) Impulse response of the CPI
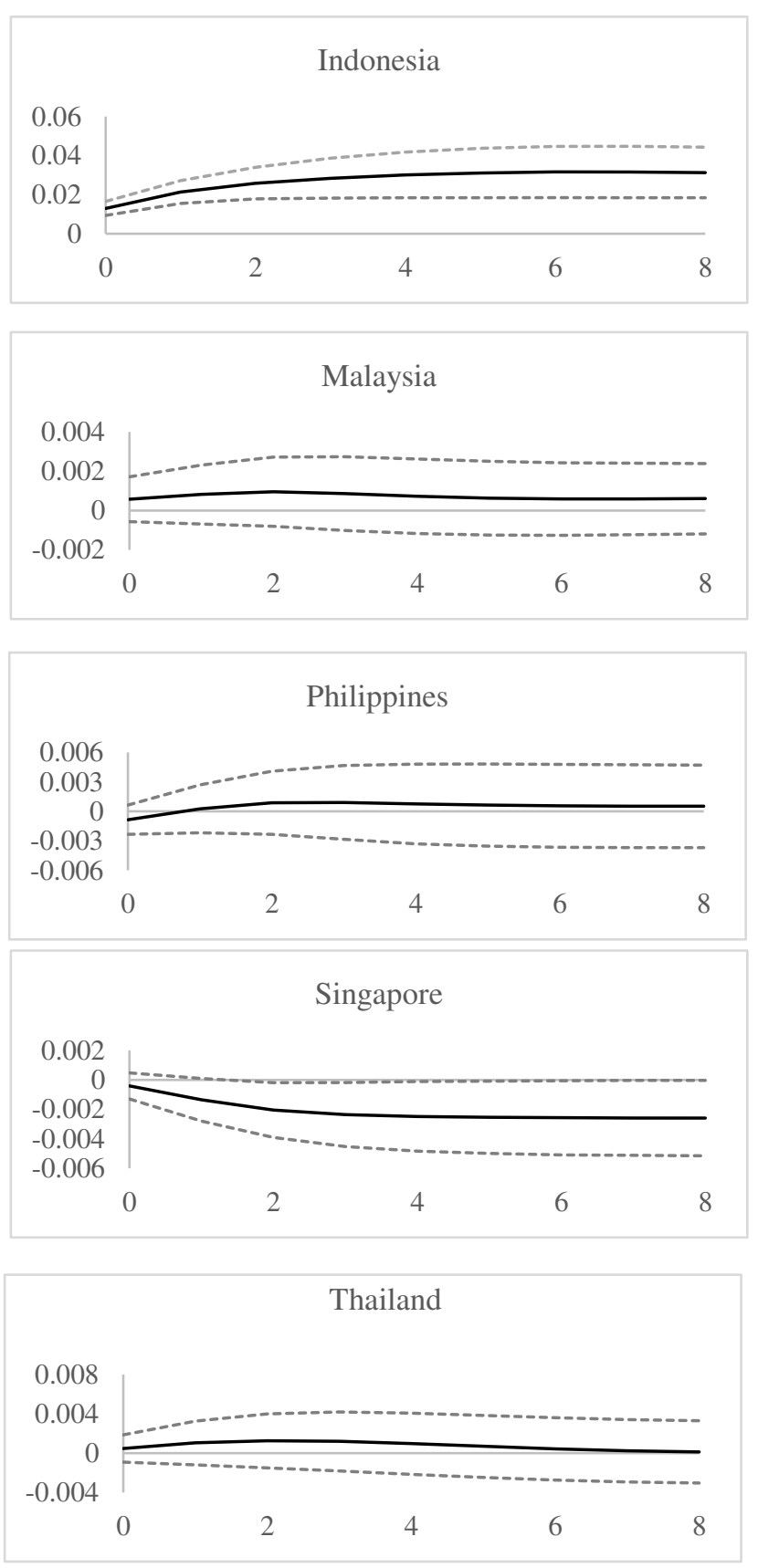

Notes: The accumulated responses of price indies in response to exchange rate shocks are represented by the solid line while the two standard error bands are covered with the two dashed lines. The lefthand side indicates the PPI response to exchange rate shocks and the right-hand side shows the CPI response. 


\section{Appendix 1. Exchange rate pass-through estimates for ASEAN countries}

\begin{tabular}{|c|c|c|c|c|}
\hline Studies & $\begin{array}{l}\text { Estimation } \\
\text { method }\end{array}$ & Period & Frequency & Sample countries \\
\hline $\begin{array}{l}\text { Baharumshah, Soon, and } \\
\text { Wohar (2017) }\end{array}$ & MSIAH & $1980-2014$ & Q & $\begin{array}{l}\text { Thailand, South Korea, the } \\
\text { Philippines, Indonesia, Japan, } \\
\text { China }\end{array}$ \\
\hline Cortinhas (2009) & VAR & $1967-2001$ & A & $\begin{array}{l}\text { Indonesia, the Philippines, } \\
\text { Malaysia, Singapore, Thailand }\end{array}$ \\
\hline Ghosh and Rajan (2009a) & DOLS & $1980-2005$ & Q & Singapore \\
\hline Ghosh and Rajan (2009b) & DOLS & $1980-2006$ & Q & Thailand, South Korea \\
\hline Ito and Sato (2008) & SVAR & 1994-2006 & Q & $\begin{array}{l}\text { Indonesia, South Korea, } \\
\text { Malaysia, Singapore, Thailand }\end{array}$ \\
\hline Parsons and Sato (2006) & $\begin{array}{l}\text { Single } \\
\text { equation }\end{array}$ & 1999-2004 & A & $\begin{array}{l}\text { Indonesia, Malaysia, the } \\
\text { Philippines, Thailand }\end{array}$ \\
\hline $\begin{array}{l}\text { Prasertnukul, Kim, and } \\
\text { Kakinaka (2010) }\end{array}$ & $\begin{array}{l}\text { ARDL and } \\
\text { VAR }\end{array}$ & $1990-2007$ & M & $\begin{array}{l}\text { Thailand, South Korea, the } \\
\text { Philippines, Indonesia }\end{array}$ \\
\hline $\begin{array}{l}\text { Soon and Baharumshah } \\
\text { (2017) }\end{array}$ & MSIAH & $1990-2015$ & Q & Malaysia \\
\hline Toh and Ho (2001) & ECM & 1975-1996 & Q & $\begin{array}{l}\text { Malaysia, Thailand, Taiwan, } \\
\text { Singapore }\end{array}$ \\
\hline Webber (1999) & VECM & 1978-1994 & Q & $\begin{array}{l}\text { South Korea, Pakistan, Thailand, } \\
\text { the Philippines, Malaysia, } \\
\text { Australia, Japan, Singapore, New } \\
\text { Zealand }\end{array}$ \\
\hline
\end{tabular}

Notes: DOLS = dynamic ordinary least square. ECM = error correction model. MSIAH = markovswitching intercept autoregressive heteroskedasticity. SVAR $=$ structural vector autoregressive. $\mathrm{VAR}=$ vector autoregressive. $\mathrm{VECM}=$ vector error correction model. $\mathrm{Q}=$ quarterly. $\mathrm{A}=$ annual. $\mathrm{M}=$ monthly. 


\section{Appendix 2. Data description}

\begin{tabular}{|c|c|c|c|c|c|}
\hline Variable & Observation & Mean & $\begin{array}{l}\text { Standard } \\
\text { deviation }\end{array}$ & Minimum & Maximum \\
\hline \multicolumn{6}{|c|}{ Indonesia (1993Q1-2012Q4) } \\
\hline CPI & 92 & 52.80 & 32.57 & 12.15 & 111.30 \\
\hline PPI & 92 & 48.10 & 34.66 & 9.33 & 114.10 \\
\hline ER & 92 & $6,784.27$ & $3,454.28$ & $1,812.69$ & $12,096.77$ \\
\hline GDP & 92 & 79.69 & 60.65 & 21.85 & 238.83 \\
\hline Interest rate & 92 & 18.47 & 5.33 & 11.59 & 35.20 \\
\hline Oil price & 92 & 42.45 & 29.13 & 12.94 & 123.95 \\
\hline \multicolumn{6}{|c|}{ Malaysia (1990Q1-2016Q3) } \\
\hline CPI & 107 & 85.42 & 16.76 & 56.26 & 115.33 \\
\hline PPI & 107 & 79.10 & 20.40 & 49.12 & 113.07 \\
\hline ER & 107 & 3.30 & 0.52 & 2.46 & 4.29 \\
\hline GDP & 103 & 40.74 & 23.94 & 11.42 & 87.31 \\
\hline Interest rate & 107 & 7.20 & 2.21 & 4.50 & 13.51 \\
\hline Oil price & 107 & 46.62 & 30.56 & 12.94 & 123.95 \\
\hline \multicolumn{6}{|c|}{ The Philippines (1993Q1-2016Q4) } \\
\hline CPI & 96 & 79.50 & 24.90 & 38.53 & 120.91 \\
\hline PPI & 96 & 76.38 & 24.03 & 37.58 & 109.60 \\
\hline ER & 96 & 42.78 & 9.36 & 24.58 & 56.28 \\
\hline GDP & 96 & 36.58 & 20.62 & 14.17 & 83.38 \\
\hline Interest rate & 96 & 10.19 & 3.72 & 5.43 & 20.70 \\
\hline Oil price & 96 & 49.70 & 30.91 & 12.94 & 123.95 \\
\hline \multicolumn{6}{|c|}{ Singapore (1990Q1-2016Q4) } \\
\hline CPI & 108 & 91.00 & 12.63 & 71.02 & 113.87 \\
\hline PPI & 108 & 90.52 & 11.39 & 74.57 & 120.37 \\
\hline ER & 108 & 1.54 & 0.18 & 1.22 & 1.88 \\
\hline GDP & 108 & 37.63 & 22.60 & 8.89 & 78.50 \\
\hline Interest rate & 108 & 5.78 & 0.70 & 5.30 & 7.89 \\
\hline Oil price & 108 & 46.64 & 30.42 & 12.94 & 123.95 \\
\hline \multicolumn{6}{|c|}{ Thailand (1993Q1-2016Q4) } \\
\hline CPI & 96 & 86.79 & 16.92 & 55.50 & 111.82 \\
\hline PPI & 96 & 77.09 & 21.62 & 45.03 & 108.60 \\
\hline ER & 96 & 34.43 & 6.02 & 24.63 & 46.55 \\
\hline GDP & 96 & 58.45 & 28.17 & 26.01 & 110.26 \\
\hline Interest rate & 96 & 8.29 & 2.82 & 5.50 & 15.25 \\
\hline Oil price & 96 & 49.70 & 30.91 & 12.94 & 123.95 \\
\hline
\end{tabular}

Notes: $\mathrm{CPI}=$ consumer price index. PPI $=$ producer price index. ER is the bilateral exchange rate between a domestic currency against US dollars. GDP is the gross domestic product in USD billions. Interest rate represents the annual lending rate and oil price measures in USD per barrel. 